\title{
EFFICIENCY OF ELECTRET POLYCARBONATE NONWOVENS IN RESPIRATORY PROTECTION AGAINST NANOPARTICLES
}

\author{
Agnieszka Brochocka \\ Central Institute for Labour Protection - National Research Institute Department of Personal Protective Equipment (Warsaw, Poland) \\ e-mail: agbro@ciop.lodz.pl; tel.: +48 4264802 25; fax.+48 4267819 15;
}

\begin{abstract}
:
Toxicological research on the influence of noxious nanoparticles on human health indicates the need to develop efficient protective devices. In particular, this concerns respiratory protective equipment employing filtration nonwovens. This paper presents a methodology for the improvement of the filtration efficiency of electret nonwovens against nanoparticles by enriching amorphous polycarbonate $(P C)$ with additives of different electrostatic potentials. We introduced perlite granules (positive charge) and amber granules (negative charge) to the polymer stream in melt-blown technology. Filtration efficiency was assessed by a standard method using paraffin oil and sodium chloride aerosol, as well as by a non-standard method using $\mathrm{NaCl}$ nanoparticles. The experiments showed that strengthening the effects of electrostatic forces by the introduction of modifiers is a promising approach to improving the efficiency of electret nonwovens against nanoparticles.
\end{abstract}

\section{Keywords:}

filtration efficiency, polycarbonate nonwoven, melt-blown process, nanoparticles

\section{Introduction}

For the past few years, nanotechnology has been observed to rapidly develop worldwide, leading to mass production of a variety of nanomaterials and, by the same token, to increased exposure of workers and consumers to them. This development has also increased social and public concerns over the safety of nanomaterials and related technologies. The importance of research and innovation for society is emphasized by the European Commission in its recently published communication entitled "EUROPA HORIZON 2020," dealing with intelligent developmentdevelopment of a knowledge- and innovation-based economy with a focus on strengthening the role of knowledge and innovation as the driving forces of the growth of the European Union.[1]

New technological applications should not only be safe in themselves but also offer significant improvements in terms of human health and environmental protection. Thus, because of the fast growth of nanomaterial production and the progress of nanomaterial engineering and nanotechnology, safety aspects must be fully explored.

Recent toxicological studies have shown that nanoparticles released by technological processes may be dangerous to humans [1-4] as a result of inhalation. [5] Consequently, of great importance in prophylaxis is the use of effective respiratory protective equipment.

Currently, researchers are working on the nonwoven structures application with different filtering layers geometrics. [6-8] Numerous efforts are also being made to modify polymer filtration materials to improve their efficiency in terms of preventing nanoaerosol penetration. $[9,13]$ Another approach to improve the effectiveness of filtration materials involves strengthening of the electrostatic attraction between the fibers and noxious aerosol particles. Studies [14-18] show that the electrostatic activation of fibers significantly improves the efficiency of filtration without increasing air flow resistance. The most common materials used in respiratory protective devices are manufactured using the melt-blown technology.

One of the mechanisms to improve the particle capture capacity by filtration materials is their electrostatic activation $[15,19]$ whereby the charged particles are attracted to or repelled from the fibers according to the direction of the electric field, while the particles are electrically neutral, they are polarized and move in accordance with the electric field gradient.[20] Today, we can distinguish multiple activation methods that are widely described in the literature, for example,[18] electrospinning, the production of ultra-thin fibers from the solution with the electric field[21]; charging using the triboelectric effect that transfers electric charges during manufacture of needle felt[14,22]; and the corona discharge using the interaction of ionized gas. Electrets are typically produced by corona discharge, fiber surface modification by low-temperature plasma $[23,24]$ or by the introduction of additives, such as fluorine or natural resin, to the structure of polymer fibers.[25]

From the point of view of respiratory protection, it is essential that the electret effect be constant over time. Unfortunately, numerous reports have shown that the particles of liquid aerosols deposited within electrets lead to loss of their filtration effectiveness over time, which is particularly dangerous if such respiratory protective equipment is used for protection against nanoaerosols.[26,27]

The nonwovens used in respiratory protective equipment are made of polypropylene (PP), mainly due to its good processing 
properties and low price. However, PP has been found to perform poorly in terms of electrostatic properties and, in particular, the durability of electret effects, which undermines its usability for protection against harmful nanoparticles. A study performed by Brochocka et al.[28] has shown that electret meltblown PP fibers may be modified to improve their filtration by the addition of modifiers with different electrostatic potentials at the fiber-forming step. Modification with perlite granules (positive potential) and positive corona discharge increased the filtration effectiveness of electrets to a greater degree than modification with amber granules (negative potential) combined with positive corona discharge.

Thus, it is necessary to seek new methods for the improvement of electret filtration effectiveness to ensure the safety of the users of protective equipment in case the assumed protection level of that equipment is compromised. One of the ways of attaining this goal is to use another thermoplastic polymer (with appropriate modifications) in place of the commonly used semicrystalline polypropylene.

From the point of view of materials used for respiratory protection, amorphous polycarbonate (PC) exhibits some valuable properties, such as considerable thermal resistance, resistance to sterilization conditions, good shape stability, good electroinsulating properties, biological inertness, ease of recycling, and ease of fiber formation.[29]

Currently, in the European market, there are not many filtering materials produced by the melt-blown technique that would be characterized by a good ability to maintain electrostatic charges in time.[30] It is very difficult to get a filtering material for manufacturing reusable filtering half masks for respiratory protection that would display both high filtration efficiency and low breathing resistance.

Thus, this work presents technological research aimed at developing appropriate modifications of electret melt-blown PC nonwovens. The objective was to produce filtering materials from PC and to improve the effectiveness of electret melt-blown $\mathrm{PC}$ nonwovens in respect of nanoparticles using modifiers with different electrostatic potentials.

\section{Experimental}

\subsection{Materials}

The raw material for the production of filtering nonwovens was PC LEXAN $144 \mathrm{R}$ granulate with a density of $1.20 \mathrm{~g} / \mathrm{cm}^{3}$ (from General Electric Company, USA). The properties of this PC material obtained from the manufacturer are given in Table 1. Listed parameters such as melting point and melting flow index (MFI) are crucial for melt-blown process.

\section{Modifiers}

Two granulates were used in the process of modification:

- natural resin (amber) with negative potential (from EDAN, Poland),

- volcanic rock (perlite) with positive potential (from TERMOFOR-BEŁCHATÓW, Poland).

A Quanta F 200 scanning electron microscope (SEM) with 500x magnification was used to examine the granulates in terms of granule shape and size (see Figures 1 and 2).

\subsection{Processing equipment}

Technological work was conducted at the experimental stand of the Central Institute for Labour Protection-National Research Institute (CIOP-PIB), which was described in detail by Brochocka and Majchrzycka (see Figure 3).[25]

Predried PC granulate was fed from the hopper to the heated extruder cylinder. It was brought to appropriate viscosity before extrusion from the fiber-forming die. Compressed air was passed from the regulator to the heat exchange unit, where it was dried and heated up to the desirable temperature. Subsequently, it was supplied to the fiber-forming die, and, upon exiting, it blew the polymer streams into elementary fibers, which were deposited on the collector to form a cohesive, porous nonwoven fabric. The nonwoven fabric production setup had certain control points to adjust the desired technological parameters. Table 2 gives the parameters used for the formation of PC nonwovens.

Given parameters were chosen as they have the most effect on the shape of the obtained fibers-diameter. There were no decomposition effects of PC observed during the process at given temperatures. The structural characteristics of the generated PC nonwovens before the modification process and after the process are presented in Table 3.

The modifiers were added in the form of granules at the fiberforming step in the amount of $5 \%$ of PC weight, according to patent, [30] in a manner described at in detail by by Brochocka and Majchrzycka.[25] Figure 4 presents the PC nonwoven without modifiers, and Figures 5 and 6 show the distribution of modifiers in the filtering nonwoven.

The modifier located on a rotatable dispenser was supplied to a line connecting the injector fed with compressed air. Produced aerosol was administered directly into the stream of semiliquid polymer. The mixture of fibers and modifier particles were collected on the surface of the collecting device to form a dense nonwoven fleece with modifier uniformly distributed.

Table 1. Characteristics of the PC according to the manufacturer

\begin{tabular}{|c|c|c|c|}
\hline Polymer type & Melting point (0C) & MFI (g/10 min) & Degree of crystallinity (\%) \\
\hline $\begin{array}{c}\text { Polycarbonate } \\
\text { LEXAN type 144 R }\end{array}$ & $280-310$ & 15.40 & Amorphous \\
\hline
\end{tabular}




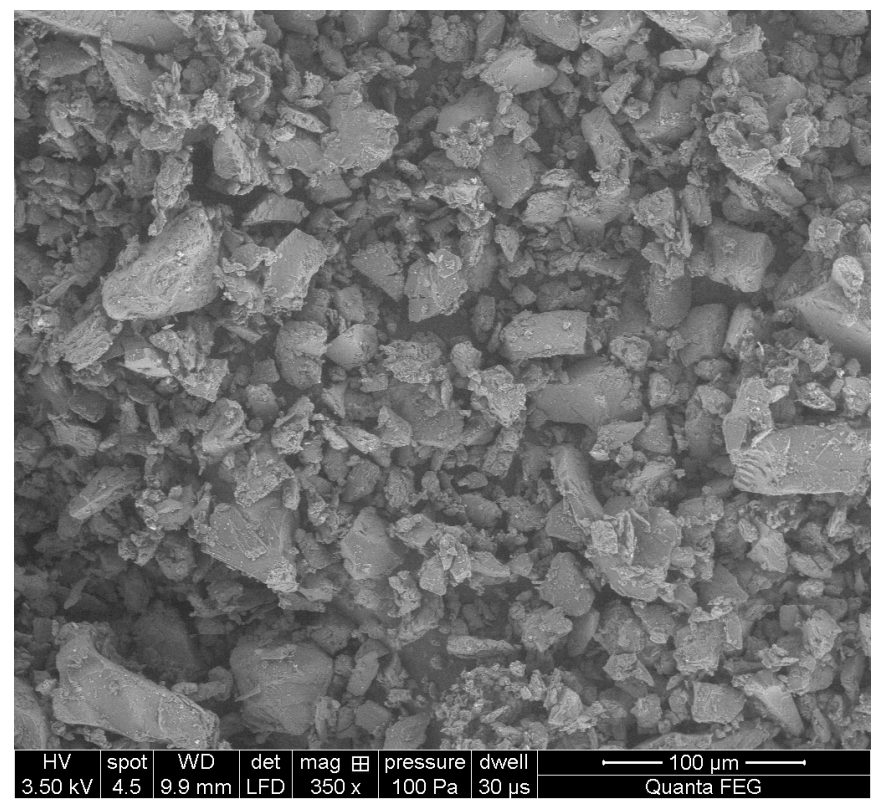

Figure 1. SEM image of amber granulate surface

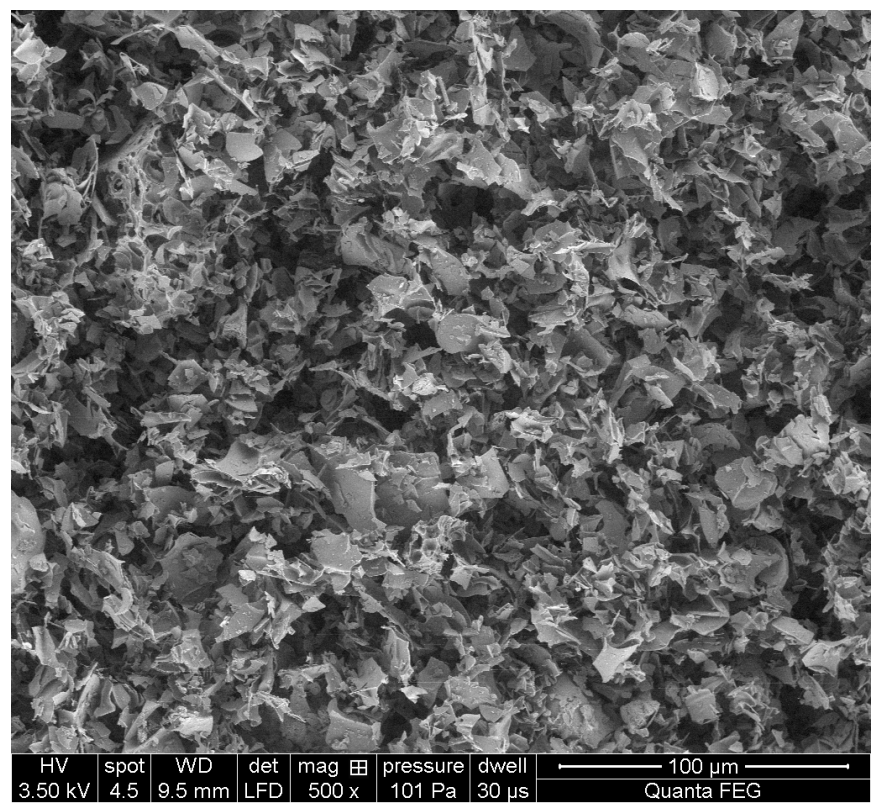

Figure 2. SEM image of perlite granulate surface

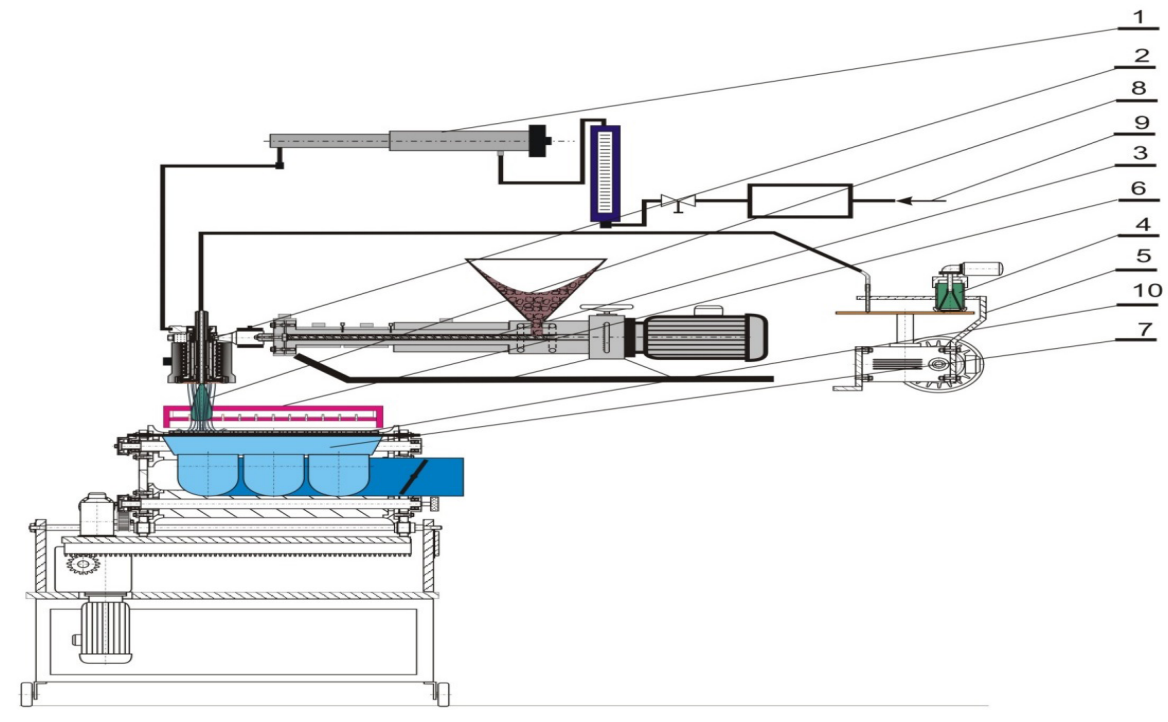

Figure 3. Setup for producing melt-blown filtering materials with modifiers in the form of powders: (1) air heater, (2) fiber-forming die, (3) extruder, (4) modifiers, (5)dispenser of modifiers, (6) electrostatic activator, (7) air suction, (8) fibers, (9) compressed air inlet, (10) collector

Table 2. Technological parameters of melt-blown production

\begin{tabular}{|l|c|}
\hline Technological parameters of the process & PC \\
\hline Temperature of the first zone of the extruder, ${ }^{\circ} \mathrm{C}$ & 315 \\
\hline Temperature of the second zone of the extruder, ${ }^{\circ} \mathrm{C}$ & 340 \\
\hline Air temperature, ${ }^{\circ} \mathrm{C}$ & 400 \\
\hline Nozzle temperature, ${ }^{\circ} \mathrm{C}$ & 370 \\
\hline Air flow rate, $\mathrm{m}^{3} \mathrm{~h}$ & 3.2 \\
\hline Polymer flow rate, $\mathrm{g} / \mathrm{min}$ & 12.0 \\
\hline Nozzles to collector distance, $\mathrm{cm}$ & 13.0 \\
\hline Collector speed, $\mathrm{m} / \mathrm{s}$ & 0.3 \\
\hline Supply voltage heating elements nozzle, $\mathrm{V}$ & 190 \\
\hline
\end{tabular}


Table 3. Structural parameters nonwoven PC without and with modifier

\begin{tabular}{|c|c|c|c|c|c|c|}
\hline $\begin{array}{c}\text { Type of } \\
\text { nonwoven }\end{array}$ & Basis weight $\left(\mathbf{g} / \mathbf{m}^{2}\right)$ & $\begin{array}{c}\text { Thickness } \\
(\mathbf{m m})\end{array}$ & $\begin{array}{c}\text { Min fiber } \\
\text { diameter } \\
(\mu \mathbf{m})\end{array}$ & $\begin{array}{c}\text { Max fiber } \\
\text { diameter } \\
(\mu \mathrm{m})\end{array}$ & $\begin{array}{c}\text { Mean fiber } \\
\text { diameter } \\
(\mu \mathrm{m})\end{array}$ & $\begin{array}{c}\text { Standard } \\
\mathbf{d e v i a t i o n}(\mathbf{m m})\end{array}$ \\
\hline $\begin{array}{c}\text { PC without } \\
\text { modifier }\end{array}$ & $90 \pm 5$ & 1.46 & 0.26 & 3.6 & 1.04 & 0.61 \\
\hline $\begin{array}{c}\text { PC with } \\
\text { modifier }\end{array}$ & $95 \pm 5$ & 1.50 & 0.20 & 3.8 & 1.11 & 0.66 \\
\hline
\end{tabular}

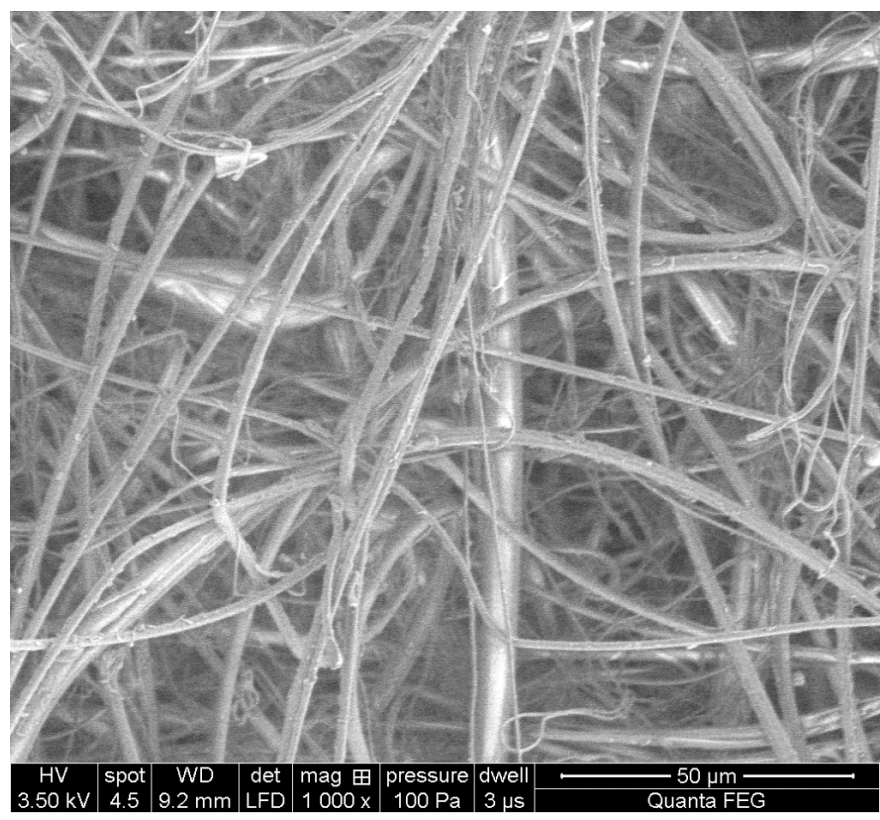

Figure 4. Nonwoven polycarbonate (PC) without the modifier

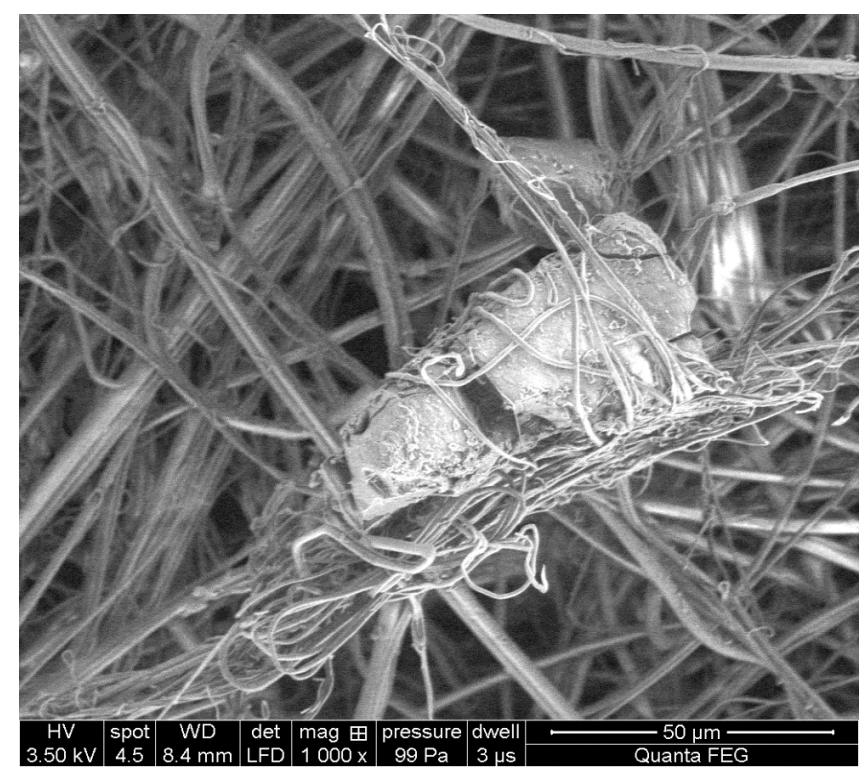

Figure 5. Nonwoven polycarbonate $(\mathrm{PC})$ with amber granules

Figure 7 shows how the modifier was distributed using a device introducing modifier into a stream of the polymer. The basic idea of this method is to supply a fiber-channel head with a screw that allows mixing and pressing the polymer melt and modifiers that are inserted continuously to the head channel.

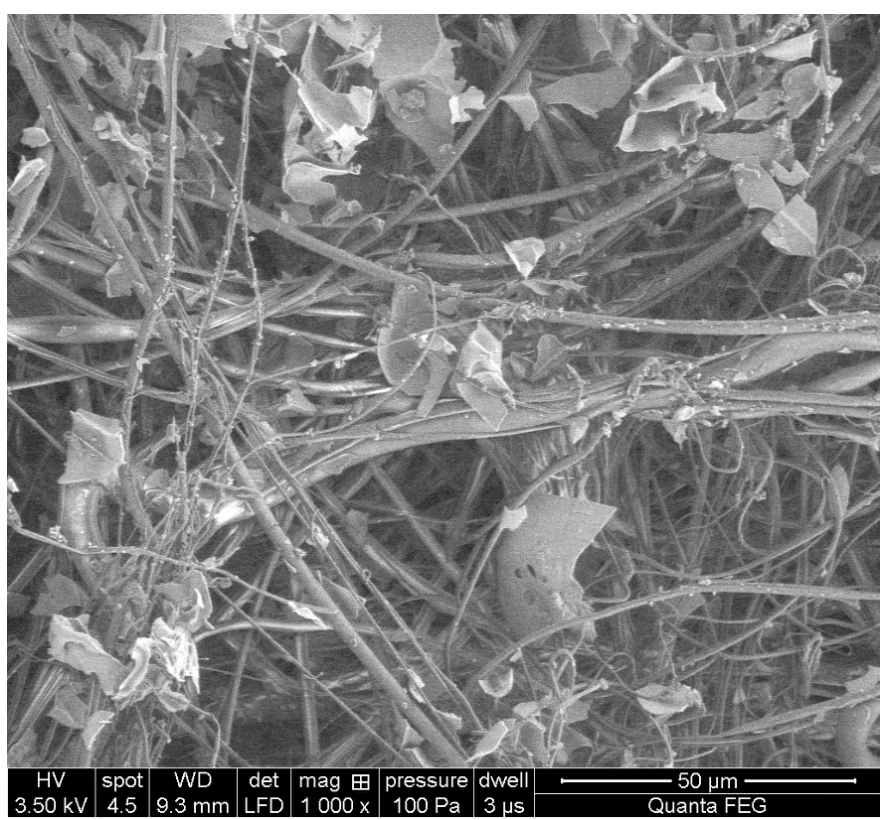

Figure 6. Nonwoven polycarbonate $(\mathrm{PC})$ with perlite granules

A corona discharge device was used to impart electret properties to the PC nonwovens with and without modifiers. It was equipped with positive multipoint electrodes placed near the nonwoven collector and a negative counter electrode placed under the take-up screen. The total charging voltage was $30 \mathrm{kV}$, which resulted in a current of $300 \pm 50 \mu \mathrm{A}$. Such a setup makes it possible to control the flow of charges, which do not become dispersed.

\subsection{Testing methods}

The efficiency of the filtering materials was established by measuring particle penetration, that is, the number of particles that were not retained by these materials. Particle penetration and air flow (breathing) resistance were examined using the methods of respiratory protective equipment evaluation specified in the relevant standards $[29,30]$ as well as using the non-standard method described further on. The standard measurements involved two model aerosols: sodium chloride and paraffin oil mist.

In the designed (not standard) test method, sodium chloride $(\mathrm{NaCl})$ was used in the form of a suspension generated from a $0.1 \%$ water solution by means of a Collison atomizer. The nanoaerosol was passed through a desiccator and ion neutralizer and fed into the chamber holding a tested nonwoven sample. Figure 8 presents the size distribution of the nanoaerosol generated by the Collison atomizer. 


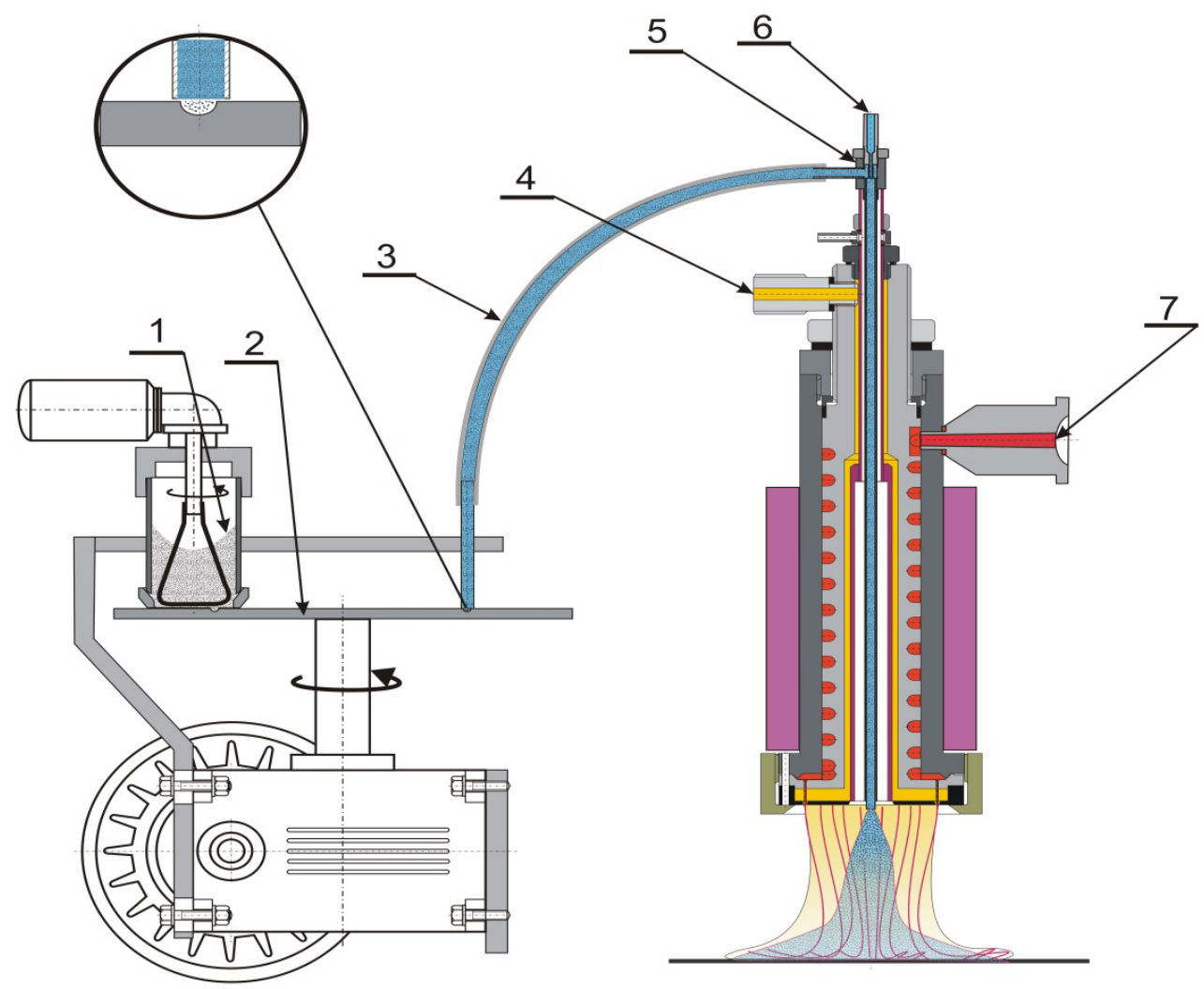

Figure 7. Head unit and fiber-insertion device of powdery modifier. (1) Modifier, (2) dispenser, (3) connecting tube, (4) hot air, (5) injector, (6) compressed air, and (7) melted polymer.

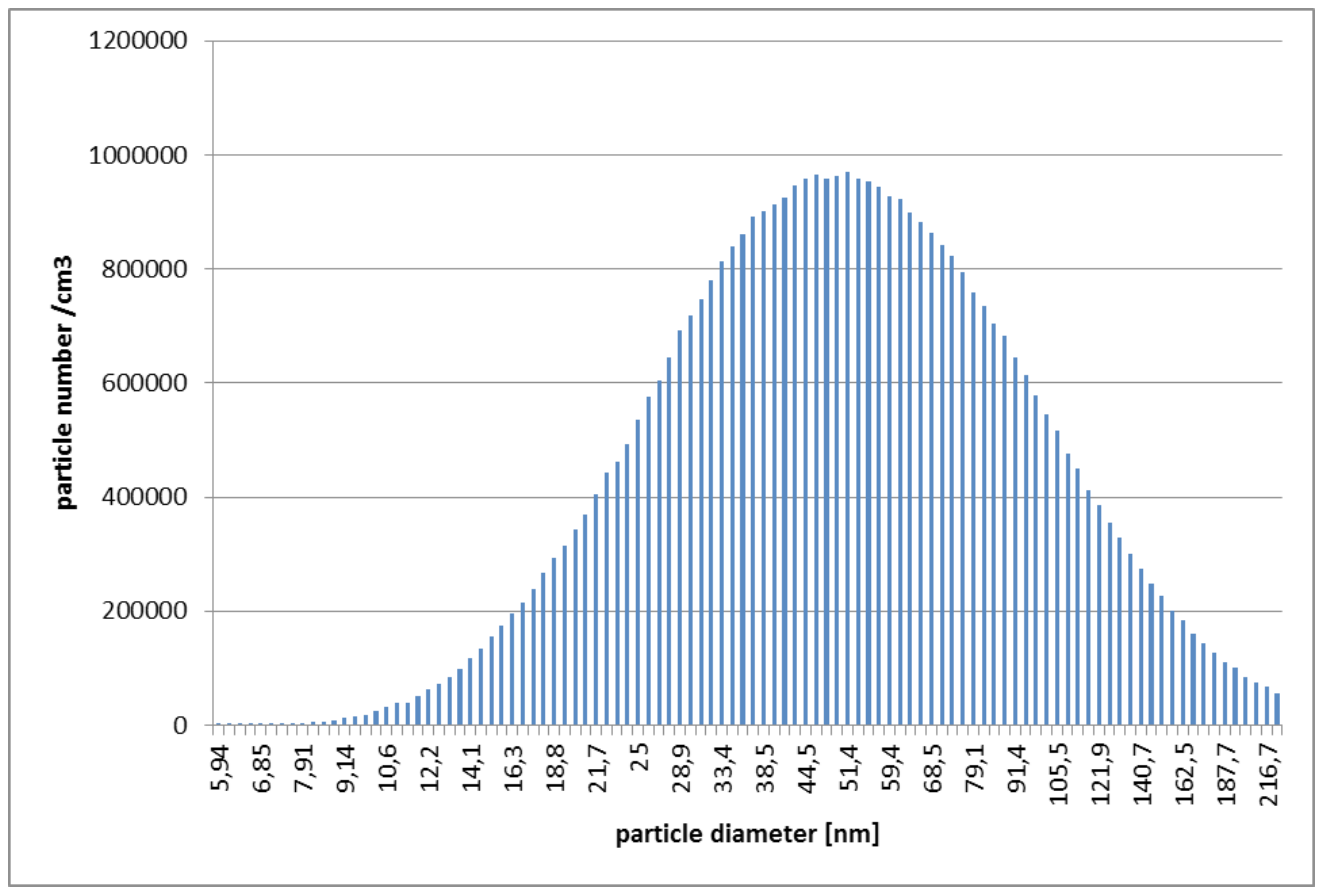

Figure 8. Dimensional distribution of $\mathrm{NaCl}$ nanoaerosol

The standard method of $\mathrm{NaCl}$ penetration test is based on the flame photometry, and the non-standard method is based on condensation particle counter with electrostatic classifier. The first method is a mass method and gives information only on total penetration value, and the second one gives the information on penetration of each particle size class but do not give a comprehensive value.
Figure $9 \mathrm{a}$ and $\mathrm{b}$ shows an atomic force microscopic image of the studied nanoaerosol, which enables the determination of the particle shape and size. It is an example of the series of the pictures that were taken to assess the physical properties of the nanoaerosols. The sample surfaces were examined by the NanoScope 3D (veeco) equipped with extremely sharp hydrophobic probe using tapping mode. 


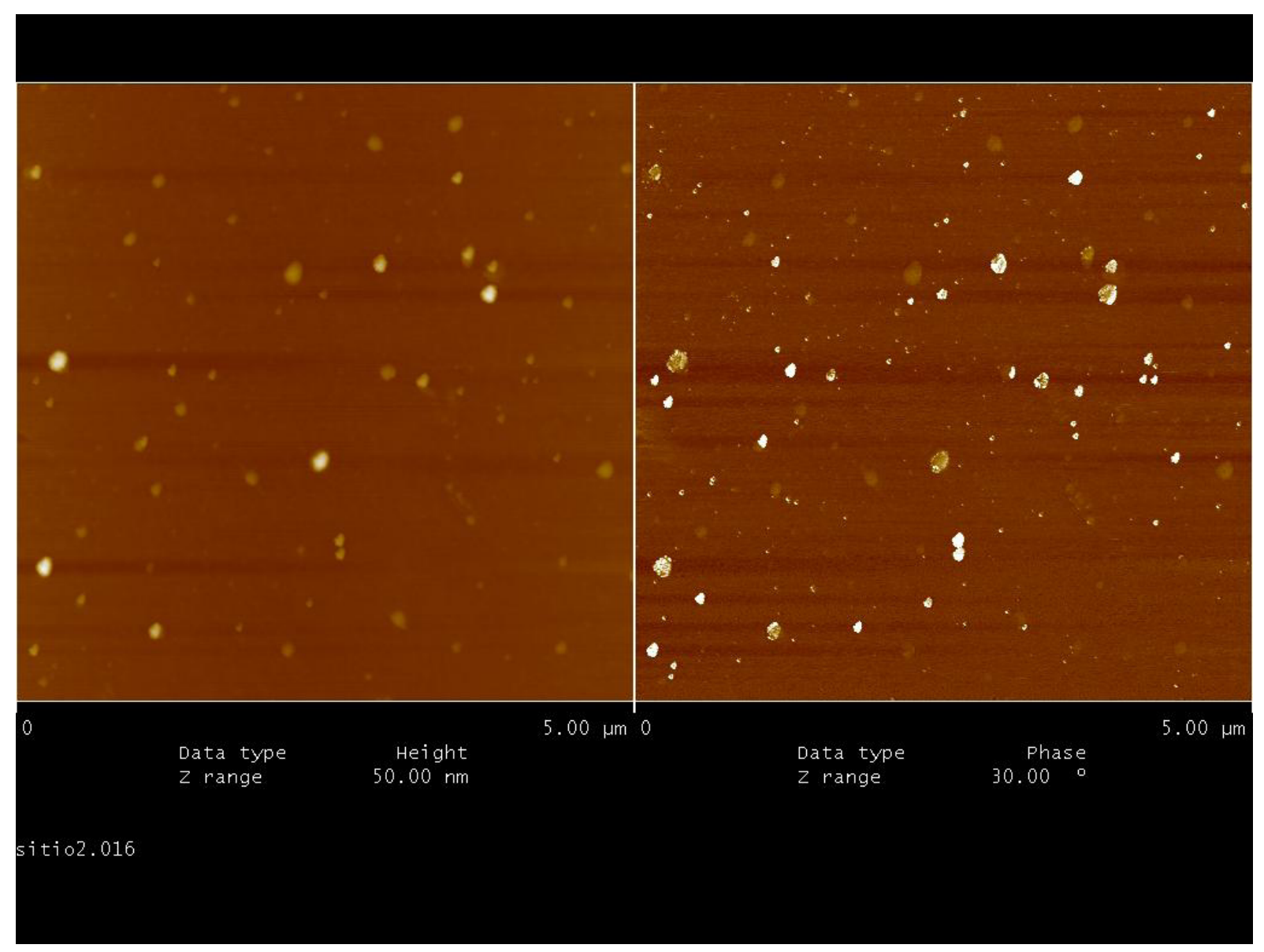

Figure 9. (a) $\mathrm{NaCl}$ nanoaerosols: 2D view

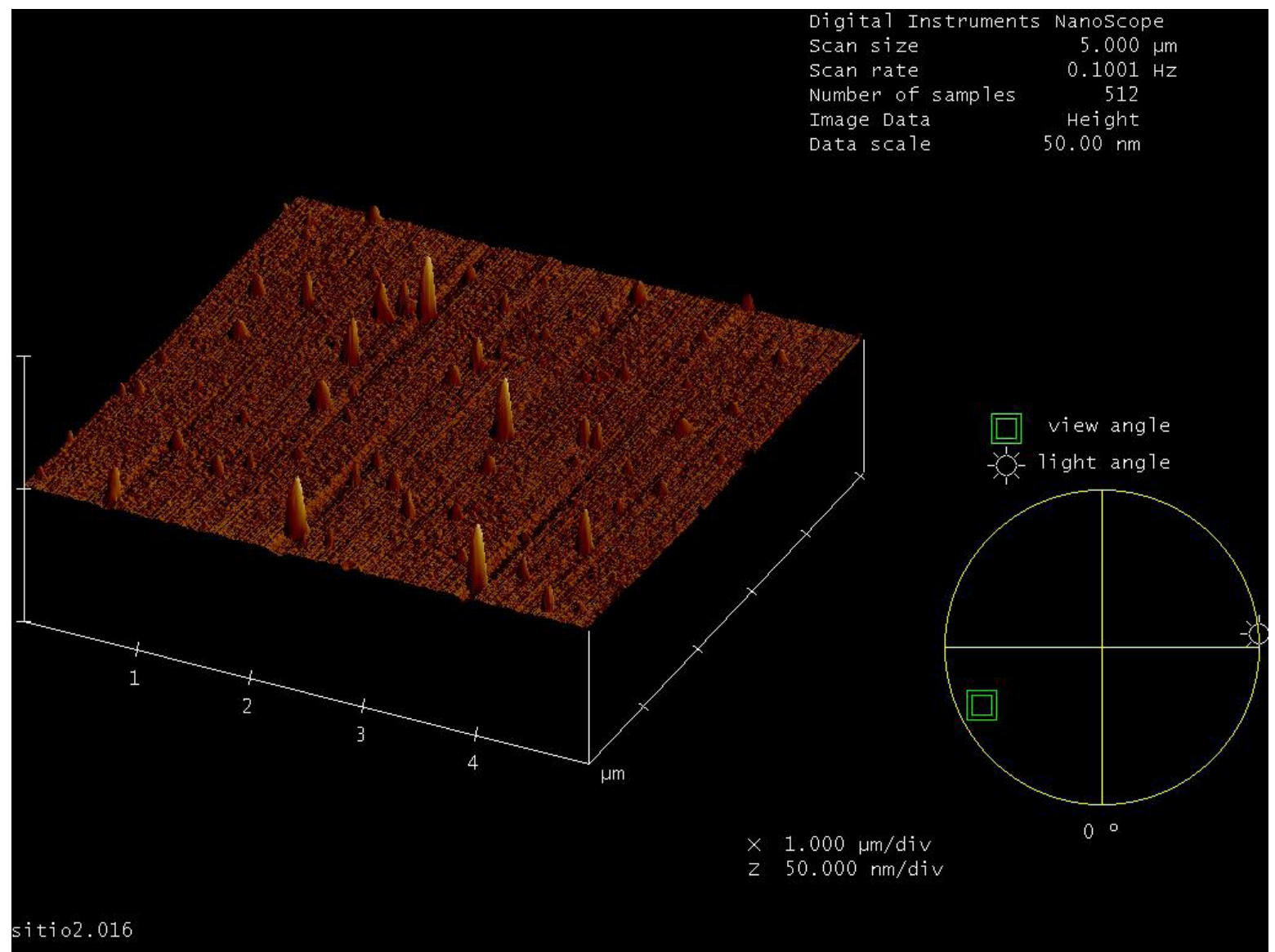

Figure 9. (b) $\mathrm{NaCl}$ nanoaerosols: 3D view 
The $\mathrm{NaCl}$ nanoparticles used in the study were cubical with a similar fractal dimension (3). The $\mathrm{NaCl}$ aerosol was used for the tests as nonhazardous. In accordance with previous tests, the shape of particles with nanometric dimensions is not significant determinant for filter penetration in accordance with classical filtration theory.[10] They were neutralized by means of an ion neutralizer and exhibited a dielectric constant of 5.9.

The penetration of nanoparticles through the filtering nonwovens was examined using a 3800 electrostatic classifier and a 3775 condensation nanoparticle counter, both from TSI. The measurement range of the setup was from 7 to $270 \mathrm{~nm}$, with 90 size classes. The test time was set to $7 \mathrm{~min}$ so as to enable the calculation of the average penetration value for three cycles of $126 \mathrm{~s}$ each, including $15 \mathrm{~s}$ breaks between them for the purpose of resetting the electrostatic particle classifier. The tests were carried out at an aerosol flow of $5,400 \mathrm{~L} / \mathrm{h}$. The area of the tested samples was $0.01 \mathrm{~m}^{2}$ and constant for all measurements. The climatic conditions during the tests were $20 \pm 5^{\circ} \mathrm{C}$ air temperature and $50 \pm 20 \%$ relative air humidity.

A diagram of the experimental stand is presented in Figure 10.

The measurement results were statistically analyzed to confirm the effect of the introduced modifiers to the nonwoven fabrics on penetration of aerosols. This statistical analysis included
- calculation of mean values, variance, as well as standard deviations for $50-275 \mathrm{~nm} \mathrm{NaCl}$ nanoparticle penetration;

- the Shapiro-Wilk test for normality of distribution;

- the Fisher-Snedecor test for comparison of variances and either the Student t-test (in the case of equal variances) or the Cochran-Cox test (in the case of different variances) for pairwise comparison of means.

\section{Results and analysis}

Table 4 shows the results for standard aerosol particle penetration, that is, for sodium chloride (mean particle diameter of $0.6 \mu \mathrm{m}$ ) and paraffin oil mist (mean particle diameter of 0.3 $\mu \mathrm{m})$ determined in accordance with the methods commonly used for the evaluation and classification of equipment for respiratory protection against harmful aerosols such as dust, smoke, and mist. Figures 11 and 12 present the results for $\mathrm{NaCl}$ nanoparticle penetration through the modified and unmodified nonwovens, including classification into nanoparticle size classes, while Table 5 gives mean results for particles ranging from 50 to $275 \mathrm{~nm}$.

The results presented in Table 4 confirm that the use of corona discharge during melt-blown fiber formation significantly increases the efficiency of removing pollutant particles from the stream of flowing air. The number of particles penetrating

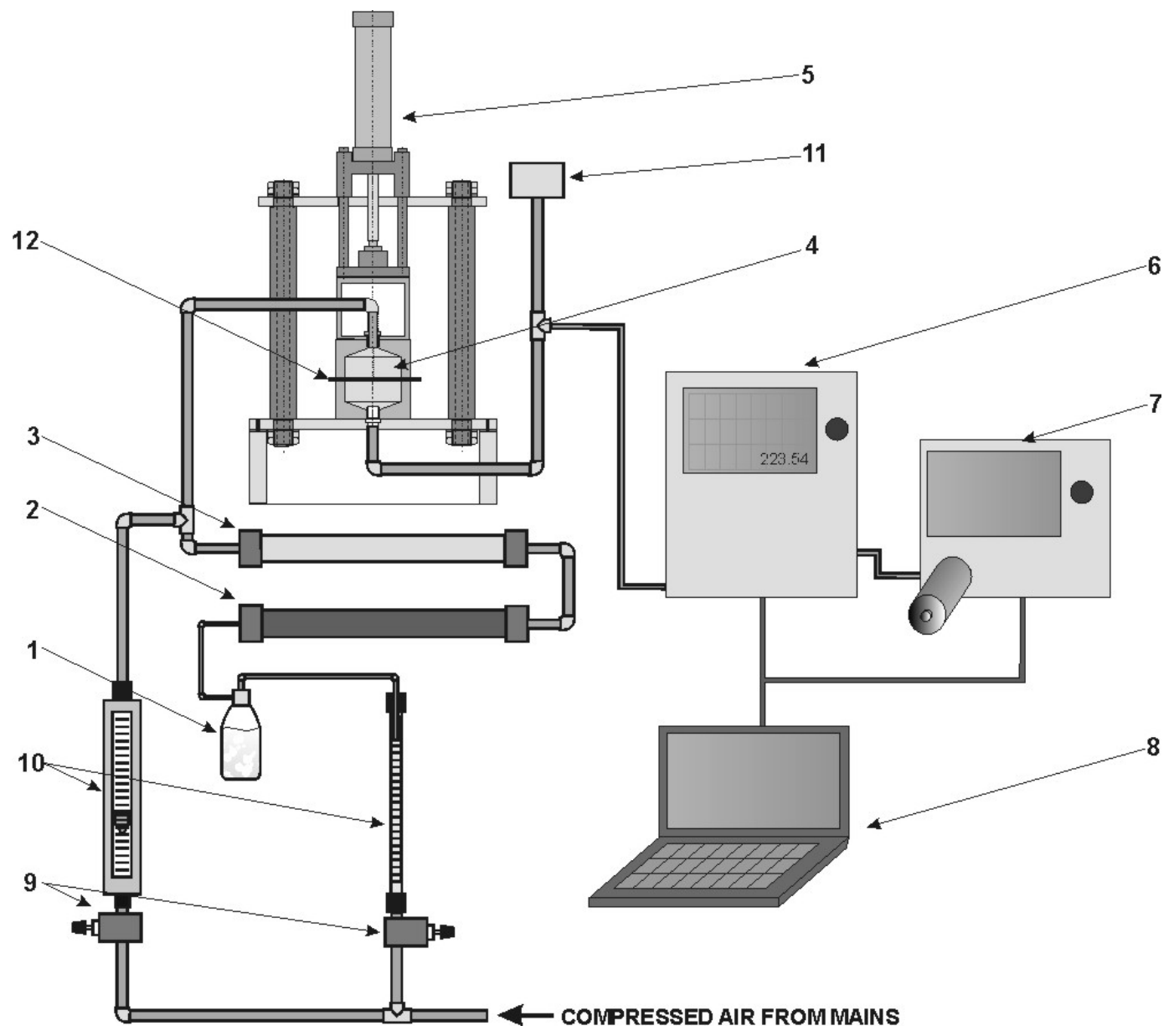

Figure 10. Setup for testing nanoparticle penetration through the filtering materials and elements: (1) nanoaerosol generator, (2) desiccant, (3) electrostatic charge neutralizer, (4) testing chamber, (5) pneumatic actuator, (6) electrostatic particle classifier, (7) condensation nanoparticle counter, (8) computer, (9) compressed air valve, (10) flow meter, (11) high-performance industrial filter, (12) tested sample 
Table 4. Filtering parameters of nonwoven fabrics determined by standard methods ${ }^{[29,30] .}$

\begin{tabular}{|l|c|c|c|}
\hline Nonwoven type & $\begin{array}{c}\text { Mean sodium chloride } \\
\text { aerosol penetration (\%) }\end{array}$ & $\begin{array}{c}\text { Mean paraffin oil mist } \\
\text { aerosol penetration (\%) }\end{array}$ & Mean air resistance (Pa) \\
\hline Polycarbonate nonwoven, charged & 0.686 & 2.624 & 238.9 \\
\hline $\begin{array}{l}\text { Polycarbonate nonwoven, } \\
\text { uncharged }\end{array}$ & 7.601 & 11.475 & 197.5 \\
\hline $\begin{array}{l}\text { Perlite-modified polypropylene } \\
\text { nonwoven, charged }\end{array}$ & 0.299 & 1.148 & 268.2 \\
\hline $\begin{array}{l}\text { Perlite-modified polypropylene } \\
\text { nonwoven, uncharged }\end{array}$ & 3.628 & 6.188 & 235.7 \\
\hline $\begin{array}{l}\text { Amber-modified polycarbonate } \\
\text { nonwoven, charged }\end{array}$ & 0.539 & 3.025 & 215.1 \\
\hline $\begin{array}{l}\text { Amber-modified polycarbonate } \\
\text { nonwoven, uncharged }\end{array}$ & 4.585 & 10.825 & 207.3 \\
\hline
\end{tabular}

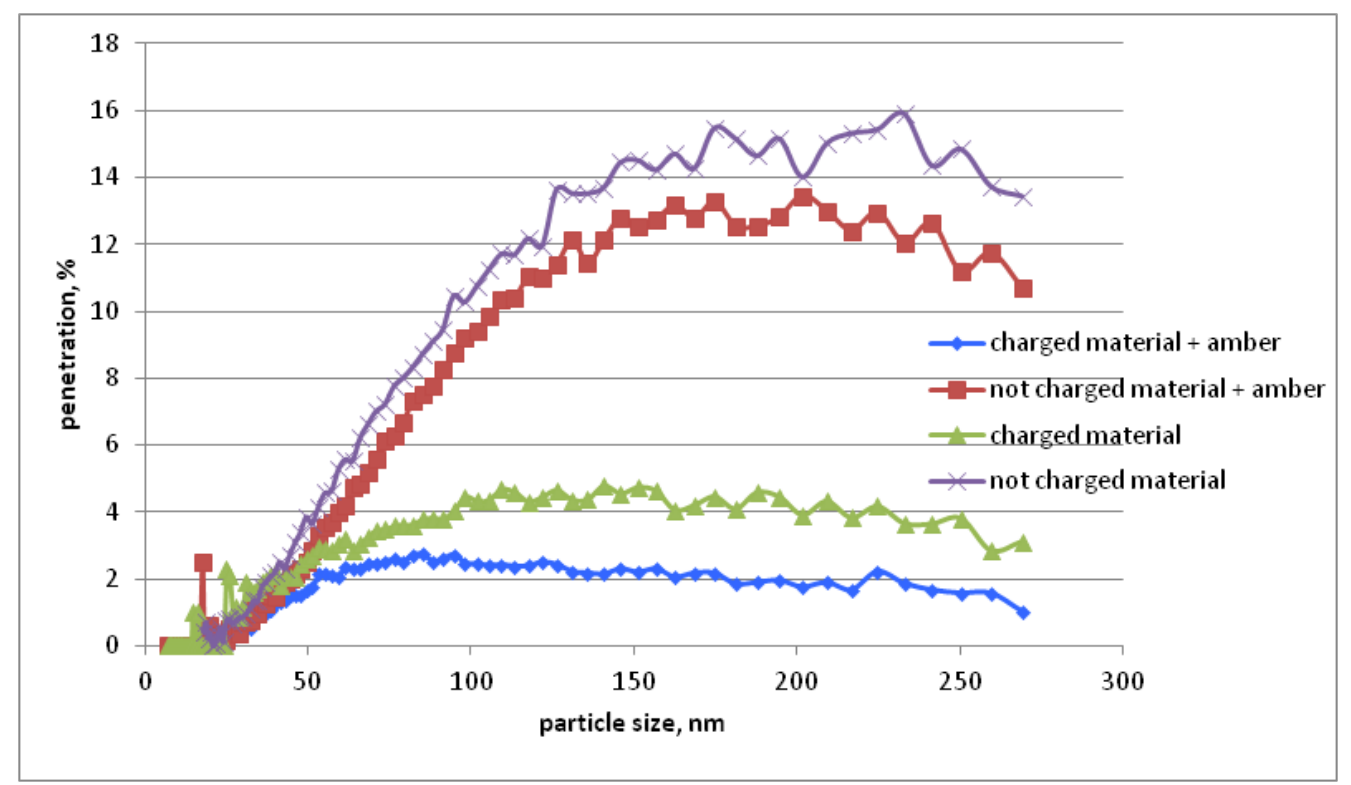

Figure 11. $\mathrm{NaCl}$ nanoparticles penetration results by electret nonwovens $\mathrm{PC}$ with and without modifier in the form of amber granules

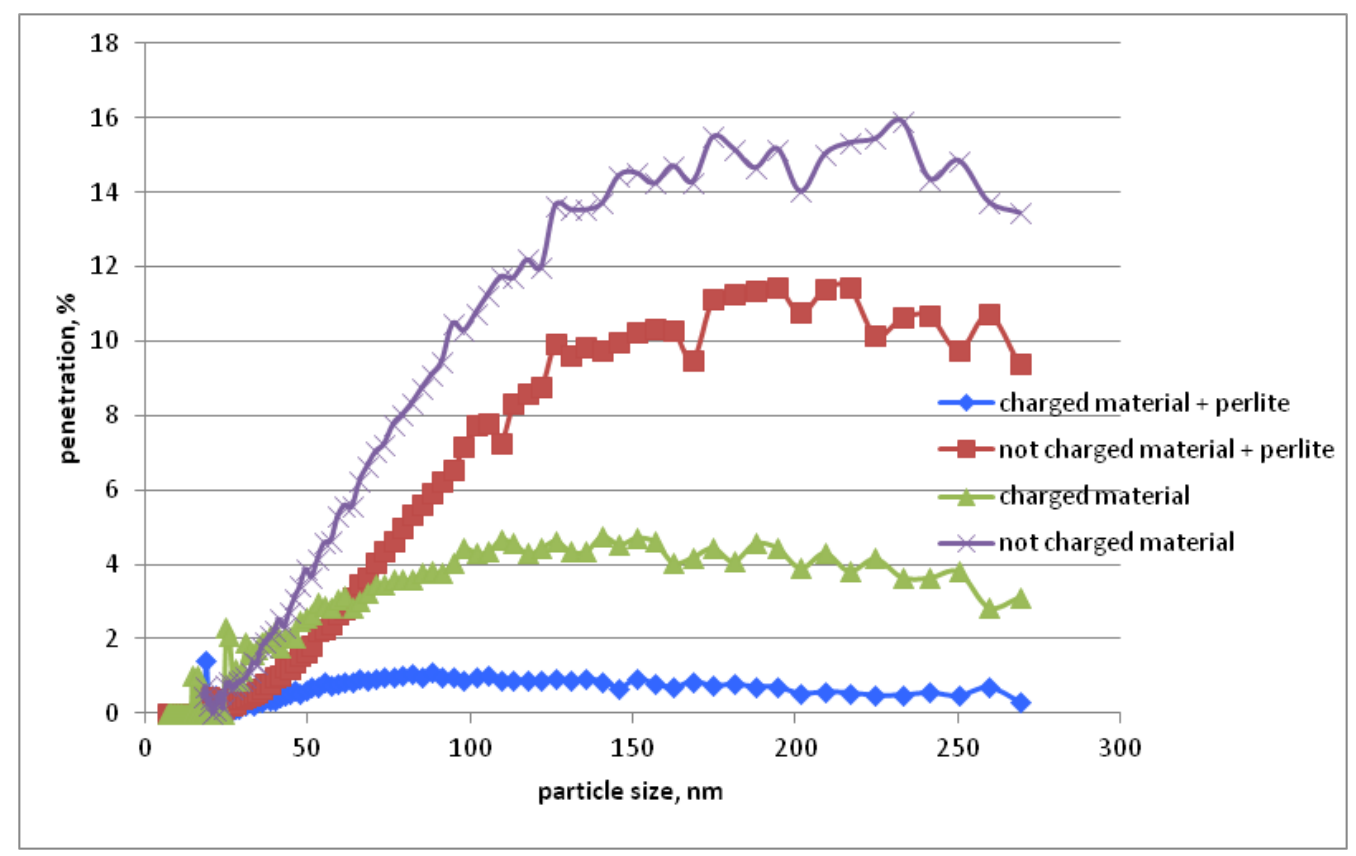

Figure 12. $\mathrm{NaCl}$ nanoparticles penetration results by electret nonwovens $\mathrm{PC}$ with and without modifier in the form of perlite granules 
through the filtering electret nonwovens is much lower than that in the case of the non-electret variants, for both modified and unmodified nonwovens. The standard measurements involve two types of particles, that is, solid $\mathrm{NaCl}$ particles and liquid paraffin particles, and their penetration rates differ for the same nonwoven variants. The different particle sizes in these aerosols and their electrostatic properties lead to differences between liquid particles (mists) and solid particles (dusts) in the mechanism of their deposition on fibers. At the same time, it should be emphasized that the use of modifiers with different electric potentials (perlite and amber) increased the efficiency of the electret nonwovens as compared to the unmodified nonwovens. The results obtained for $\mathrm{NaCl}$ nanoparticle penetration were quite different. Figures 11 and 12 present the relationship between penetration rate and nanoparticle size for the nonwovens modified with amber and perlite granules, respectively. In the case of the non-electret nonwovens, the introduction of modifiers did not lead to significant changes in the efficiency of nanoparticle deposition on PC fibers. Here, the prevalent mechanism of nanoparticle deposition involved forces of mechanical attraction, the effectiveness of which largely depends on pore size. One of the effects of the modification of nonwoven fabric is the reduction of pore sizes, which also has the effect on improving the filtration efficiency. [28] However, the use of modifiers in the electret nonwovens triggered the expected increase in their efficiency as compared to unmodified electret nonwovens. This effect depends on nanoparticle size and is most pronounced in the range of 50-200 nm. Owing to the fact that, according to standard,[32] protective respiratory filtration equipment is evaluated in respect of a certain mean particle size characteristic of a given aerosol type, mean penetration rates were also calculated for the nanoparticles (Tables 5 and 6 ). The results show that the best variant in terms of the lowest nanoparticle penetration rate is the electret nonwoven modified with perlite (positive potential). This is also confirmed by the plot of penetration rates for nanoparticles of different size (Figure 12).

The differences in nanoparticle penetration through particular nonwoven variants were analyzed to determine the statistically significant differences. The results of statistical analysis are presented in the form of a matrix in Table 6 . The statistical tests were conducted at a statistical significance of $\alpha=0.05$. The a level is the probability of rejecting the null hypothesis: modification of nonwoven fabrics improves filtration efficiency.
If the $\alpha$ level is 0.05 , then the conditional probability of a type I error, rejection of given hypothesis, is $5 \%$.

Statistical analysis confirmed our expectations and the abovementioned hypothesis that modification of nonwoven fabrics improves filtration efficiency. Irrespective of the type of modifier used, all the variants of melt-blown nonwovens displayed an air flow resistance (respiratory resistance) of 197-270 Pa (Table 4). This confirms that the studied melt-blown fiber modification method improves the efficiency of the filter material against nanoparticles, while only slightly affecting the respiratory discomfort of the user. At the same time, it should be stressed that the resistance levels reported in this study are commonly found in respiratory protective equipment of comparable efficiency, which have breathing resistance on the some level. $[34,35]$

\section{Conclusions}

Presented method for the production of electret melt-blown PC nonwoven with modification by the addition of modifiers with different electrostatic potentials to amorphous PC improves filtration efficiency (fewer particles penetrate through the filtration nonwoven). As a result of modification with perlite granules (positive potential) combined with positive corona discharge, the electret exhibited better filtration properties than in the case of amber granulate (negative potential) with positive corona discharge. A similar effect was obtained by introducing these modifiers to PP electret melt-blown nonwovens.[29] The use of modifiers with the same charge sign as corona discharge led to greater electrostatic potential. This effect does not depend on whether the polymer is of crystalline nature or not.

\section{ACKNOWLEDGEMENTS}

This publication draws on the results obtained as part of the Operational Programme Innovative Economy (OP IE) 20072013, Priority 1: "Research and development of modern technologies," Measure 1.1 "Support for scientific research for the development of a knowledge-based economy," Submeasure 1.1.2 "Strategic programmes of scientific research and development"; as well as on the OP IE Project 01.01.02-

Table 5. Mean $\mathrm{NaCl}$ nanoparticle penetration through the nonwoven fabrics with and without modifier

\begin{tabular}{|c|c|c|c|c|c|c|}
\hline & $\begin{array}{c}\text { Amber- } \\
\text { modified PC } \\
\text { nonwoven with } \\
\text { electrostatic } \\
\text { charges }\end{array}$ & $\begin{array}{c}\text { Amber- } \\
\text { modified PC } \\
\text { nonwoven } \\
\text { without } \\
\text { electrostatic } \\
\text { charges }\end{array}$ & $\begin{array}{c}\text { Perlite- } \\
\text { modified PC } \\
\text { nonwoven with } \\
\text { electrostatic } \\
\text { charges }\end{array}$ & $\begin{array}{c}\text { Perlite- } \\
\text { modified PC } \\
\text { nonwoven } \\
\text { without } \\
\text { electrostatic } \\
\text { charges }\end{array}$ & $\begin{array}{c}\text { PC nonwoven } \\
\text { with } \\
\text { electrostatic } \\
\text { charges }\end{array}$ & $\begin{array}{c}\text { PC nonwoven } \\
\text { without } \\
\text { electrostatic } \\
\text { charges }\end{array}$ \\
\hline Mean & 2.19 & 10.88 & 0.80 & 7.60 & 3.88 & 11.09 \\
\hline $\begin{array}{l}\text { Standard } \\
\text { deviation }\end{array}$ & 0.41 & 2.13 & 0.20 & 2.76 & 0.56 & 3.32 \\
\hline Variance & 0.17 & 4.55 & 0.04 & 7.62 & 0.32 & 11.02 \\
\hline
\end{tabular}


Table 6. List of statistical test results

\begin{tabular}{|c|c|c|c|c|c|c|}
\hline I & $\begin{array}{c}\text { Amber- } \\
\text { modified PC } \\
\text { nonwoven with } \\
\text { electrostatic } \\
\text { charges }\end{array}$ & $\begin{array}{l}\text { Amber-modified } \\
\text { PC nonwoven } \\
\text { without } \\
\text { electrostatic } \\
\text { charges }\end{array}$ & $\begin{array}{c}\text { Perlite- } \\
\text { modified PC } \\
\text { nonwoven } \\
\text { with } \\
\text { electrostatic } \\
\text { charges }\end{array}$ & $\begin{array}{c}\text { Perlite- } \\
\text { modified PC } \\
\text { nonwoven } \\
\text { without } \\
\text { electrostatic } \\
\text { charges }\end{array}$ & $\begin{array}{c}\text { PC nonwoven } \\
\text { with } \\
\text { electrostatic } \\
\text { charges }\end{array}$ & $\begin{array}{c}\text { PC } \\
\text { nonwoven } \\
\text { without } \\
\text { electrostatic } \\
\text { charges }\end{array}$ \\
\hline \multicolumn{7}{|l|}{$\begin{array}{c}\text { Amber- } \\
\text { modified PC } \\
\text { nonwoven } \\
\text { with } \\
\text { electrostatic } \\
\text { charges }\end{array}$} \\
\hline \multirow{2}{*}{$\begin{array}{c}\text { Amber- } \\
\text { modified PC } \\
\text { nonwoven } \\
\text { without } \\
\text { electrostatic } \\
\text { charges }\end{array}$} & $\begin{array}{c}\text { Statistically } \\
\text { significant } \\
\text { differences }\end{array}$ & & & & & \\
\hline & $\begin{array}{c}\text { mean } A<\text { mean } \\
B\end{array}$ & & & & & \\
\hline \multirow{2}{*}{$\begin{array}{c}\text { Perlite- } \\
\text { modified PC } \\
\text { nonwoven } \\
\text { with } \\
\text { electrostatic } \\
\text { charges }\end{array}$} & $\begin{array}{c}\text { Statistically } \\
\text { significant } \\
\text { differences }\end{array}$ & $\begin{array}{l}\text { Statistically } \\
\text { significant } \\
\text { differences }\end{array}$ & & & & \\
\hline & $\begin{array}{c}\text { mean } A>\text { mean } \\
B\end{array}$ & mean $A>$ mean $B$ & & & & \\
\hline \multirow{2}{*}{$\begin{array}{l}\text { Perlite- } \\
\text { modified PC } \\
\text { nonwoven } \\
\text { without } \\
\text { electrostatic } \\
\text { charges }\end{array}$} & $\begin{array}{c}\text { Statistically } \\
\text { significant } \\
\text { differences }\end{array}$ & $\begin{array}{l}\text { No statistically } \\
\text { significant } \\
\text { differences }\end{array}$ & $\begin{array}{c}\text { Statistically } \\
\text { significant } \\
\text { differences }\end{array}$ & & & \\
\hline & $\begin{array}{c}\text { mean } \mathrm{A}<\text { mean } \\
\mathrm{B}\end{array}$ & mean $A=$ mean $B$ & $\begin{array}{c}\text { mean } A< \\
\text { mean } B\end{array}$ & & & \\
\hline \multirow{2}{*}{$\begin{array}{l}\text { PC nonwoven } \\
\text { with } \\
\text { electrostatic } \\
\text { charges }\end{array}$} & $\begin{array}{c}\text { Statistically } \\
\text { significant } \\
\text { differences }\end{array}$ & $\begin{array}{c}\text { Statistically } \\
\text { significant } \\
\text { differences }\end{array}$ & $\begin{array}{c}\text { Statistically } \\
\text { significant } \\
\text { differences }\end{array}$ & $\begin{array}{c}\text { Statistically } \\
\text { significant } \\
\text { differences }\end{array}$ & & \\
\hline & $\begin{array}{c}\text { mean } \mathrm{A}<\text { mean } \\
\mathrm{B}\end{array}$ & mean $\mathrm{A}>$ mean $\mathrm{B}$ & $\begin{array}{c}\text { mean } A< \\
\text { mean } B\end{array}$ & $\begin{array}{c}\text { mean } A> \\
\text { mean } B\end{array}$ & & \\
\hline \multirow{2}{*}{$\begin{array}{l}\text { PC nonwoven } \\
\text { without } \\
\text { electrostatic } \\
\text { charges }\end{array}$} & $\begin{array}{c}\text { Statistically } \\
\text { significant } \\
\text { differences }\end{array}$ & $\begin{array}{l}\text { No statistically } \\
\text { significant } \\
\text { differences }\end{array}$ & $\begin{array}{l}\text { Statistically } \\
\text { significant } \\
\text { differences }\end{array}$ & $\begin{array}{c}\text { No statistically } \\
\text { significant } \\
\text { differences }\end{array}$ & $\begin{array}{c}\text { Statistically } \\
\text { significant } \\
\text { differences }\end{array}$ & \\
\hline & $\begin{array}{c}\text { mean } \mathrm{A}<\text { mean } \\
\mathrm{B}\end{array}$ & mean $A=$ mean $B$ & $\begin{array}{c}\text { mean } A< \\
\text { mean } B\end{array}$ & $\begin{array}{c}\text { mean } A= \\
\text { mean } B\end{array}$ & $\begin{array}{c}\text { mean } A< \\
\text { mean } B\end{array}$ & \\
\hline
\end{tabular}

10-018/09 entitled: "Innovative polymer and carbon materials for protection of the respiratory system against nanoparticles, vapours and gases."

\section{References}

[1] Savolainen K., Backman U., BrouwerD., FadeelB., Fernandes T., Kuhlbusch T., Landsiedel R., Lynch I., Pylkkanen L.(2013), Nanosafety in Europe 2015-2025: Towards Safe and Sustainable Nanomaterials and Nanotechnology Innovations, EDITA, Helsinki 2013, ISBN 978-952-261-310-3.

[2] Linkov I. et al.(2009), Emerging methods and tools for environmental risk assessment, decision-making, and policy for nanomaterials: summary of NATO Advanced Research Workshop, Journal of Nanoparticle Research 11 (2009) 513-527.
[3] Warheit D.B., Sayes Ch.M., Reed K.L., Swain K.A.(2008), Health effects related to nanoparticle exposures: environmental, health and safety considerations for assessing hazards and risks, Pharmacology and therapeutics, 120,35-42, 2008.

[4] Brouwer D., Van Duuren-Stuurman B., Berges M., Jankowska E., Bard D., Mark D.(2009), From workplace air measurement results toward estimates of exposure? Development of a strategy to assess exposure to manufactured nano-objects. J Nanopart Res. 2009;11(8):1867-1881. DOI 10.1007/s11051-009-9772-1.

[5] Friedrichs S., Schulte J. (2007), Environmental, health and safety aspects of nanotechnology implications for the $R \& D$ in (small) companies, Science and Technology of Advanced Materials 8 (2007) 12-18. 
[6] Hoyt V. W., Mason E.(2008), Nanotechnology: emerging health issues, Journal of Chemical Health \& Safety (III/IV 2008) 10-15.

[7] Podgórski A., Balazy A., Gradoń L. (2006), Application of Nanofibers to Improve the Filtration Efficiency of the Most Penetrating Aerosol Particles in Fibrous Filters, Chem. Eng. Sci. 61:6804-6815.

[8] Gradoń L., Podgórski A., Balazy A. (2005), Filtration of Nanoparticles in the Nanofibrous filters. FILTECH EUROPA 2005 - Conference Proceedings, Wiesbaden, Germany, vol. II, 178-185.

[9] Brochocka A. (2001), Characteristics of melt-blown filter materials produced by simultaneous blowing of polymer melt from two extruders, Fibres \& Textiles in Eastern Europe, 66-69.

[10] Brochocka A., Makowski K., Majchrzycka K.(2012), Penetration of different nanoparticles through melt-blown filter media used for respiratory protective devices, Textile Research Journal, Vol.82(18), 1906-919

[11] Yang W., Peters J.I., Williams R.O. III (2008), Inhaled nanoparticles - A current review, International Journal of Pharmaceutics 356: 239-247.

[12] Brochocka A., Majchrzycka K., Makowski K., Grzybowski P. (2013), Efficiency of Filtering Materials Used in Repiratory Protective Devices Against Nanoparticles, JOSE 2013, Vol.19 No. 2, 285-295.

[13] Kim S.Ch., Harrington M.S., Pui D.Y.H. (2007), Experimental study of nanoparticles penetration through commercial filter media, Journal of Nanoparticle Research 9, 117-125.

[14] Brochocka A., Ruszkowski K.(2000), Some aspects of manufactiring electret nonwoven filters by a conventional method with utilisation of the triboelectric effect - Fibres and Textiles in Eastern Europe, July/September 2000, No. 3, Vol.8, 69-72.

[15] Fjeld R.A., Ownes T.M.(1998), The Effect of Particle Charge on Penetration in an Electret Filter, IEEE Transactions on Industry Applications, Vol. 24, No 4, 1988, 725-731.

[16] Tsai P.P., Wadsworth Larry C.(1995), Electrostatic Charging of Melt Blown Webs for High-Efficiency Air Filters, in: Advances in Filtration and Separation Technology, American Filtration and Separation Society, Vol.9, 473, 1995.

[17] Tsai P.P., Wadsworth Larry C.(1996), Effect of Polymer Properties on the Electrostatic Charging of Different Media Structures for Air Filters, Conference Proceedings, SPE, ANTEC 96, Indianapolis, 3642.

[18] Tsai P.P., Schreuder-Gibson H., Gibson P. (2002) Different Electrostatic Methods for Making Electret Filters, Journal of Electrostatics, 54, 2002, 333-341.

[19] Brown, R. C., Wake, D., Gray, R., Blackford, D. B., i Bostock, G. J. (1988), Effect of industrial aerosols on the performance of electrically charged filter material. Ann Occup Hyg, 32 (3), strony 271-294.

[20] Wang, C. S. (2001),. Electrostatic forces in fibrous filters a review. Powder Technology, 118 (1-2), strony 166-170.
[21] Ramakrishna, S., Fujihara, K., i Teo, W.E. (2005), An Introduction to Electrospinning and Nanofibers. World Scientific Publishing Co. Pte Ltd.

[22] Krucińska, I. (2001). The influence of technological parameters on the filtration efficiency of electret needled non-woven fabrics. Journal of Electrostatics, 56 (2), strony 143-153.

[23] Urbaniak-Domagała W., Wrzosek H., Szymanowski H., Majchrzycka K., Brochocka A.(2010) Plasma Modification of Filter Nonwovens Used for the Protection of Respiratory Tracts, Fibres \& Textiles In Eastern Europe 2010; Vol. 18, No 6(83); 94-99.

[24] Gui-qiu Ma, Jing-jiang Zhai, Ben Liu, Ding-hai Huang, Jing Sheng (2012) Plasma modification of polypropylene surface and grafting copolimerization of styrene onto polypropylene , Chinese Journal of Polymer Science, Vol.30, No.3, 2012, 423-435.

[25] Brochocka A., Majchrzycka K. (2009) Technology for the Production of Bioactive Melt-Blown Filtration Materials Applied to Respiratory Protective Devices. Fibres \& Textiles in Eastern Europe. 2009;17(5): 2-98.

[26] Stephen B. Martin Jr, Ernest S. Moyer. 2000. Electrostatic Respirator Filter Media: Filter Efficiency and Most Penetrating Particle Size Effects. Applied Occupational and Environmental Hygiene, Vol. 15:(8) 609-617;

[27] Huang H.L., Wang D.M., Kao S.T., Yang S., Huang Y.Ch. 2007. Removal of monodisperse liquid aerosols by using the polysulfone membrane filters. Separation and Purification Technology 54:96-103

[28] Brochocka A., Majchrzycka K., Makowski K. (2013) Modified Melt-Blown Nonwovens for Respiratory Protective Devices Against Nanoparticles - Fibres and Textiles in Eastern Europe 2013, 21, 49(100), 106-111.

[29] Donnald G. Legrand, John T.Bendler, Handbook of Polycarbonate Science and Technology, Marcel Dekker, New York, NY 10016, 2000

[30] Rengasamy S., Miller A., Vo E., Eimer B. C. 2013. Filter Performance Degradation of Electrostatic N95 and P100 Filtering Facepiece Respirators by Dioctyl Phthalate Aerosol Loading. Journal of Engineered Fibers and Fabrics, Volume 8, (3 ): 62-69);

[31] Patent. Poland, No. 212 2007, (2011)

[32] Standard EN 13274-7: 2008 Respiratory protective devices. Methods of test. Part 7: Determination of particle filter penetration.

[33] Standard EN 13274-3:2001 Respiratory protective devices. Methods of test. Part 3: Determination of breathing resistance.

[34] Krucińska I., Strzembosz W., Majchrzycka K., Brochocka A., Sulak K., Biodegradable Particle Filtering Half-masks for Respiratory Protection, FIBRES \& TEXTILES in Eastern Europe 2012; 20, 6B(96): 77-83.

[35] Brochocka A., Makowski K., Filtering half masks for respiratory protection against nanoparticles - containing aerosols, Chemical Industry, 93/1/2014: 93-98. 